Zeszyty Naukowe Szkoły Głównej Gospodarstwa Wiejskiego w Warszawie

Problemy Rolnictwa Światowego tom 18 (XXXIII), zeszyt 3, 2018: 80-90

DOI: $10.22630 /$ PRS.2018.18.3.68

Andrzej Czyżewski $^{1}$, Jakub Staniszewski ${ }^{2}$

Uniwersytet Zielonogórski

Uniwersytet Ekonomiczny w Poznaniu

\title{
Zrównoważona intensyfikacja rolnictwa jako kombinacja efektywności nakładów ekonomicznych i środowiskowych
}

\section{Sustainable Intensification of Agriculture as the Composition of Economic Productivity and Environmental Pressure Measures}

\begin{abstract}
Synopsis. W artykule zaprezentowano alternatywną koncepcję pomiaru zrównoważonej intensyfikacji (SI), opartą o pomiar efektywności z wykorzystaniem metody DEA, indeksu TFP Malmquista oraz miar odległości euklidesowej i kątowej. Proponowany miernik pozwala określić dynamikę procesu zrównoważonej intensyfikacji, z uwzględnieniem pierwotnego poziomu efektywności nakładów ekonomicznych i ekoefektywności. Zastosowane rozwiązanie pozwala częściowo zniwelować problem ważenia poszczególnych wymiarów zrównoważonego rozwoju. Metodę zastosowano do pomiaru SI w krajach Unii Europejskiej w latach 2005-2013. Uzyskane wyniki potwierdzają występowanie tego procesu w większości krajów oraz przeciętnie w całej UE. Szczególnie szybko postępował on wśród krajów Europy środkowo-wschodniej oraz wśród krajów skandynawskich Zmiany niezgodne $\mathrm{z}$ koncepcją zrównoważonej intensyfikacji postępowały natomiast $\mathrm{w}$ krajach Beneluksu oraz na Wyspach Brytyjskich, gdzie następowała poprawa produktywności środowiskowej, kosztem produktywności nakładów ekonomicznych.
\end{abstract}

Słowa kluczowe: zrównoważona intensyfikacja, rolnictwo, ekoefektywność, DEA, Malmquist, TFP

\begin{abstract}
The paper presents an alternative method of sustainable intensification (SI) measurement. It is based on efficiency analysis using DEA method, Malmquist TFP index and Euclidean and angular distance measurements. The proposed measure makes it possible to determine the dynamics of the process of sustainable intensification, taking into account the base level of economic and ecoefficiency. Applied solution partially eliminates the problem of weighing the various dimensions of sustainable development. The method was used to measure SI in the European Union countries in 2005-2013. Obtained results confirm the presence of this process in most countries and on average in the whole EU. It was particularly fast among the countries of Central and Eastern Europe and among the Scandinavian countries. Changes that were not in line with the SI concept, occurred in the Benelux countries and in the British Isles, where environmental productivity improved, diminishing economic productivity.
\end{abstract}

Key words: sustainable intensification, agriculture, eco-efficiency, DEA, Malmquist, TFP

JEL Classification: Q01, Q56, B41

\footnotetext{
${ }^{1}$ prof. zw. dr hab., Katedra Ekonomii Międzynarodowej, Uniwersytet Zielonogórski, ul. Podgórna 50, 65-246 Zielona Góra, e-mail: a.czyzewski@wez.uz.zgora.pl; https://orcid.org/0000-0002-6233-6824 ${ }^{2}$ dr, Katedra Makroekonomii i Gospodarki Żywnościowej UE w Poznaniu, Al. Niepodległości 10, 61-875 Poznań, e-mail: jakub.staniszewski@ue.poznan.pl; https://orcid.org/0000-0001-8074-0911
} 


\section{Wprowadzenie}

Wśród najważniejszych zagadnień współczesnej ekonomii rolnej wskazać można badania prowadzone $\mathrm{w}$ ramach paradygmatu rozwoju trwale równoważonego. Tak rozumiany rozwój oznacza proces dochodzenia do celu, który również nie jest statyczny i konieczność równoważenia ładów ekonomicznych, demograficznych, przestrzennośrodowiskowych i społecznych, w sposób minimalizujący błąd złożenia (Czyżewski, 2015). W problematykę tę wpisuje się koncepcja zrównoważonej intensyfikacji (ang. sustainable intensification, SI) rolnictwa, zakładająca „poprawę całkowitej produktywności rolnictwa poprzez większą efektywność wykorzystania zasobów i zmniejszanie oddziaływania środowiskowego na jednostkę produkcji” (Lampkin, 2015, s. 9). Dekomponując to pojęcie zidentyfikować można swoisty paradoks, polegający na tym, że „pojęcie intensywności produkcji, jest $\mathrm{w}$ kontekście rolnictwa dobrze zdefiniowane i łatwo mierzalne, jednak powszechnie dyskredytowane, podczas gdy pojęcie zrównoważenia nie jest W wystarczającym stopniu zdefiniowane ani zmierzone, a mimo to ogólnie wspierane" (Buckwell i in., 2013, s. 76). W tym kontekście zasadna wydaje się synteza „ilościowych” metod pomiaru intensywności, z ,jakościowym” sposobem pojmowania świata, stanowiącym istotę paradygmatu zrównoważonego rozwoju rolnictwa (Czyżewski i Staniszewski, 2018). Szczególnie w sytuacji występowania niedostatków w dotychczasowych metodach pomiaru zrównoważenia i zrównoważonej intensyfikacji, związanych m.in. z potrzebą ważenia poszczególnych ładów (Buckwell i in., 2013, s. 30).

Wychodząc z powyższych przesłanek w opracowaniu tym autorzy proponują alternatywny sposób operacjonalizacji koncepcji zrównoważonej intensyfikacji, oparty o pomiar efektywności z wykorzystaniem metody obwiedni danych (ang. data envelopment analysis, DEA), indeksu całkowitej produktywności zasobów (ang. total factor productivity, TFP) Malmquista oraz miar odległości euklidesowej i kątowej. Proponowana miara wpisuje się w dotychczasowy nurt operacjonalizacji SI, oparty o koncepcję ekoefektywności (Staniszewski 2017b), czyli efektywności wykorzystania zasobów przyrody. W przeszłości badano już rozłącznie efektywność w wymiarze ekonomicznym (Baráth i Fertő, 2017; Floriańczyk i Rembisz, 2012) lub środowiskowym (Turčeková i in., 2015; Klepacki, Gołasa, Wysokiński 2016) na poziomie sektorowym, jednakże brak syntezy tych dwóch wymiarów. Tego typu badania prowadzone były jedynie na poziomie mikroekonomicznym (Czyżewski i Smędzik, 2010; Gadanakis i in., 2015). Lukę tę wypełnia proponowana metoda, która dodatkowo wpisuje się w potrzebę dynamicznych badań rozwoju trwale równoważonego oraz proponuje sposób obiektywizacji przyznawania wag poszczególnym wymiarom analizy. Proponowana metoda wykorzystana zostanie do pomiaru zrównoważonej intensyfikacji w krajach Unii Europejskiej. Biorąc pod uwagę związki tej koncepcji z unijną wspólną polityką rolną i strategią EUROPA 2020 (Staniszewski 2017a), przeprowadzone badania pozwolą zweryfikować hipotezę o postępującym w krajach Unii Europejskiej procesie SI.

\section{Dane i metody}

Zaproponowana metoda pomiaru składa się z trzech etapów. W pierwszym szacowane są wskaźniki efektywności nakładów ekonomicznych i środowiskowych oraz indeksy całkowitej produktywności Malmquista. W związku z powszechnością stosowania tych metod nie zostaną one szczegółowo omówione. Informację na ich temat znaleźć można m.in. w opracowaniu Färe i in. (1994). W drugim, określona zostaje optymalna ścieżka 
zrównoważonej intensyfikacji. W trzecim etapie oszacowany zostaje wskaźnik syntetyczny. Do określenia optymalnej ścieżki SI wykorzystano wartości efektywności nakładów ekonomicznych $\mathrm{i}$ środowiskowych $\mathrm{w}$ okresie bazowym, oszacowane na potrzeby wyznaczenia indeksu Malmquista. Wskaźniki te przyjmują wartości z przedziału $(0 ; 1)$ i wykorzystać je można jako współrzędne w układzie dwuwymiarowym (rys. 1A). Optymalną ścieżkę zrównoważonej intensyfikacji wyznacza kąt $\alpha_{o p t}$, opisujący nachylenie linii prowadzącej od punktu $a$ opisanego $\mathrm{w}$ układzie współrzędnych wartościami efektywności nakładów ekonomicznych $\left(x_{a}\right)$ i środowiskowych $\left(y_{a}\right)$ do punktu $e$ o współrzędnych $(1,1)$, reprezentującego pełną efektywność w obydwu wymiarach. Wartość kąta $\alpha_{o p t}$ określić można za pomocą funkcji:

$$
\alpha_{o p t}=f\left(x_{a}, y_{a}\right)=\left\{\begin{array}{cl}
\operatorname{arctg}\left(\frac{1-y_{a}}{1-x_{a}}\right), & x_{a}<1 \cap y_{a}<1 \\
0^{o}, & x_{a}<1 \cap y_{a}=1 \\
45^{\circ}, & x_{a}=1 \cap y_{a}=1 \\
90^{\circ}, & x_{a}=1 \cap y_{a}<1
\end{array}\right.
$$

Otrzymany kąt wyznaczany jest przez proporcję, w jakiej powinny znajdować się wobec siebie wartości indeksów środowiskowej i ekonomicznej produktywności sektora rolnego, aby osiągnął on możliwie szybko pełną efektywność. Przykładowo, jeżeli punkt $a$ posiadałby współrzędne $(0,8 ; 0,6)$ oznaczałoby to, że sektor rolny kraju $a$, dla osiągnięcia pełnej efektywności, obecną produkcję powinien wytwarzać wykorzystując $40 \%$ mniej zasobów środowiskowych i $20 \%$ mniej zasobów ekonomicznych niż obecnie. Większa jest zatem nieefektywność w zakresie wykorzystania zasobów środowiskowych, więc dla osiągnięcia pełnej efektywności powinna ona zmniejszać się szybciej, dokładnie dwa razy szybciej $(40 / 20=2)$. Zgodnie z równaniem (1) wartość $\alpha_{o p t}$ dla tej wartości wyniesie zaś $64,43^{\circ}$. Funkcja $f\left(x_{a}, y_{a}\right)$ posiada również kilka przypadków szczególnych. Jeżeli w okresie bazowym sektor rolny w danym kraju charakteryzuje się pełną efektywnością nakładów ekonomicznych, wówczas przyjmuje się, że optymalnym rozwiązaniem jest postęp w zakresie efektywności nakładów środowiskowych, przy zachowaniu obecnego poziomu efektywności nakładów ekonomicznych, co opisywane jest $\alpha_{o p t}=90^{\circ}$ (linia pionowa).

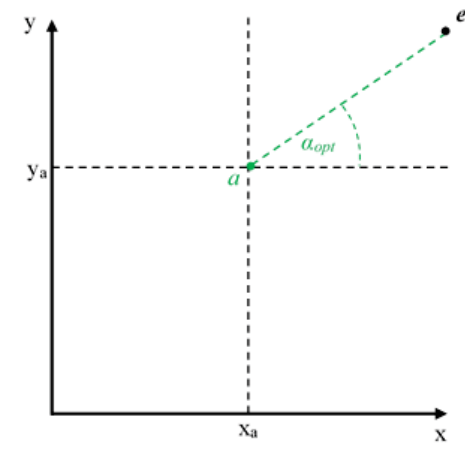

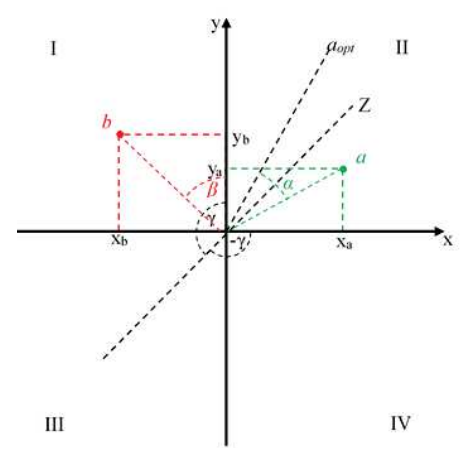

Rys. 1. Wskaźnik zrównoważonej intensyfikacji - ilustracja modelu

Fig. 1. Sustainable intensification indicator - illustration of the model

Źródło: opracowanie własne. 
Analogicznie, w przypadku pełnej efektywności nakładów środowiskowych, postulowane jest jedynie zwiększanie efektywności nakładów ekonomicznych, co oznacza $\alpha_{o p t}=0^{\circ}$ (linia pozioma). Kiedy dany sektor wykorzystuje optymalnie zarówno zasoby ekonomiczne, jak i środowiskowe, wówczas postuluje się dalszy równomierny rozwój w obydwu obszarach $\left(\alpha_{o p t}=45^{\circ}\right)$.

Metodę oszacowania wskaźnika syntetycznego zilustrować można w układzie współrzędnych (rys. 1B.). Punkty $a$ i $b$ reprezentują dwa analizowane kraje. Ich odległości od początku układu współrzędnych w poziomie (odcinki $0 x_{a}, O x_{b}$ ) reprezentują zmianę ekonomicznej produktywności rolnictwa, zaś odległość w pionie (odcinki $O y_{a}, O y_{b}$ ) zmianę produktywności środowiskowej. Wypadkową zmian w obydwu tych wymiarach obliczyć można stosując metrykę euklidesową, zgodnie ze wzorem:

$$
d\left(x_{n}, y_{n}\right)=\sqrt{x_{n}^{2}+y_{n}^{2}}
$$

Na rys. 1B odległość tą reprezentują odcinki $0 a$ i $0 b$. Jednakże poprzestanie na tej metodzie redukcji wymiarów jest niewystarczające. Identyczne wartości tak skonstruowanego wskaźnika miałyby wszystkie obserwacje znajdujące się na okręgu o środku w początku układu współrzędnych i promieniu $0 a$. Oznacza to, że tak samo zostałyby ocenione zmiany polegające na poprawie w zakresie obydwu wymiarów produktywności, jak i te polegające na „podwójnym” pogorszeniu. Dlatego niezbędne jest dodatkowe uwzględnienie kierunku zachodzących zmian. Zaproponowanym sposobem rozwiązania tego problemu jest uwzględnienie tzw. mnożnika kierunkowego $\left(M_{k}\right)$. Szacowany jest on w różny sposób, w zależności od położenia danego obiektu w określonej części układu współrzędnych. $M_{k}$ przyjmuje wartości z przedziału $\langle-2,0) \cup\langle 1,2\rangle$. Warunkiem koniecznym uzyskania dodatniej jego wartości jest przyrost produktywności ekonomicznej i środowiskowej, co równoznaczne jest z położeniem punktu w II części układu. Wszystkie znajdujące się tam punkty uznać można za reprezentujące zmiany w kierunku zrównoważonej intensyfikacji. Warunkiem dostatecznym uzyskania maksymalnej wartości $M_{k}$ jest nachylenie odcinka $O a$ zgodne z optymalną ścieżką zrównoważonej intensyfikacji $(\alpha=0)$. W miarę odchylania od tej ścieżki wartość $M_{k}$ maleje w tempie ok. 0,011 $\left(\frac{1}{90}\right)$ na $1^{\circ}$ odchylenia. Sposób obliczania $M_{k}$, można zapisać jako funkcję $f(\alpha)$, zgodnie ze wzorem:

$$
M_{k}=f(\alpha)=2-\frac{\alpha}{90^{\circ}}
$$

W przypadku niespełnienia warunku koniecznego zrównoważonej intensyfikacji $\left(x_{n}<0 \cup y_{n}<0\right)$, zmienia się sposób obliczania $M_{k}$. Jeżeli punkt reprezentujący sektor rolny danego kraju znajduje się w I, III lub IV części układu współrzędnych założono, że istotniejsze jest jak najszybsze zatrzymanie spadku produktywności ekonomicznej i środowiskowej. W takiej sytuacji ścieżką odniesienia staje się prosta $Z$, nachylona pod kątem $45^{\circ}$ w stosunku do osi x. Odchylenia od niej (zredukowane o $45^{\circ}$ ) stanowią odchylenia od ścieżki gwarantującej, co najmniej utrzymanie efektywności ekonomicznej lub środowiskowej na poziomie z okresu bazowego. Dla punktu b, znajdującego się w I części układu, a zatem charakteryzującego się dodatnim indeksem produktywności środowiskowej i ujemnym produktywności ekonomicznej, będzie to kąt $\beta$. Kąt ten przyjmuje wartości z 
przedziału $\left\langle-135^{\circ} ; 135^{\circ}\right)$. Dla punktów powyżej prostej $Z$ są to wartości dodatnie, zaś dla punktów poniżej tej prostej, wartości ujemne. Kąt $0^{\circ}$ wyrażają osie $\mathrm{x}$ i y. Miara kąta $\beta$, wyrażona w stopniach została następnie odpowiednio przeskalowana, zgodnie z funkcją:

$$
M_{k}=f(\beta)=\left\{\begin{array}{cl}
-\frac{\beta}{45^{\circ}}+2, & |\beta| \in\left(0^{\circ} ; 90^{\circ}\right\rangle \\
-\frac{\beta}{90^{\circ}}+0,5, & |\beta| \in\left(90^{\circ} ; 135^{\circ}\right)
\end{array}\right.
$$

Dla I, III i IV części układu współrzędnych $f(\beta)$ przyjmuje wartości z przedziału $(0 ;-2\rangle$, a w miarę zbliżania się $|\beta|$ do $135^{\circ}$ wartości maleją. Dla punktów w I i IV części układu wartość $M_{k}$ maleje w tempie ok. 0,011 $\left(\frac{1}{90}\right)$ na $1^{\circ}$ odchylenia, co oznacza, że $M_{k}$ przyjmuje dla nich wartości z przedziału $\langle-1,0)$. Dla punktów w części III, maleje w tempie dwukrotnie większym (ok. $0,022\left(\frac{1}{45}\right)$ na $1^{\circ}$ odchylenia), co oznacza wartości $M_{k}$ należące do przedziału $\langle-2 ;-1)$. Celem takiego rozkładu skali było określenie za pomocą znaku, czy dany obiekt rozwijał się zgodnie z założeniami zrównoważonej intensyfikacji. Tylko w przypadku ich spełnienia wartość wskaźnika kierunkowego jest dodatnia. Inną cechą $M_{k}$ jest jego nieciągłość. Nie przyjmuje on wartości z przedziału $\langle 0 ; 1)$. Związane jest to $\mathrm{z}$ faktem, że w II części układu znajdują się jednostki, których indeks produktywności ekonomicznej

i środowiskowej poprawiał się. Gdyby wartość Mk im przyporządkowana była mniejsza od jeden, wówczas jednostki byłyby „karane”, gdyż wskaźnik SI byłby zmniejszany przez ułamkowy mnożnik kierunkowy. Ułamki występują jednak w I i IV części układu. Mnożnik kierunkowy przyjmuje wówczas wartość z przedziału $\langle-1 ; 0)$. Punkty znajdujące się w tych częściach reprezentują kraje, gdzie wskaźnik produktywności poprawił się tylko $\mathrm{w}$ jednym

z wymiarów. Zważywszy na fakt, że mnożnik kierunkowy występuje w tych częściach układu ze znakiem ujemnym, uzasadnione jest ograniczenie negatywnego efektu zastosowania tego mnożnika, poprzez wprowadzenie jego ułamkowych wartości. Odróżnia to część I i III układu od części IV, gdzie mamy do czynieni z pogorszeniem obydwu wskaźników efektywności. W związku z tym mnożnik kierunkowy przyjmuje wartość (-1;-2〉. Ostatecznie wskaźnik zrównoważonej intensyfikacji, bazując na równaniach (2), (3) i (4) obliczany jest jako:

$$
S I_{a}=M_{k} \times d\left(x_{a}, y_{a}\right)
$$

Z zastosowaniem powyżej opisanych metod określono dynamikę zrównoważonej intensyfikacji rolnictwa w krajach Unii Europejskiej w latach 2005-2013. Wykaz zastosowanych w obliczeniach danych zawiera tabela 1.

Zmienne do badania dobrane zostały na podstawie wcześniejszych badań ekonomicznej (Baráth i Fertő, 2017; Floriańczyk i Rembisz, 2012) i środowiskowej (Kuosmanen, 2014; Klepacki, Gołasa, Wysokiński, 2016) efektywności rolnictwa. 
Tabela 1. Nakłady ekonomiczne, środowiskowe i efekty działalności rolniczej - mierniki Table 1. Economic and environmental inputs and outputs of the agricultural activity - measures

\begin{tabular}{|c|c|c|c|}
\hline Тур & Miernik & Opis & Kod Eurostat \\
\hline \multirow{3}{*}{ 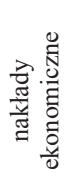 } & praca & $\begin{array}{l}\text { całkowite nakłady pracy w rolnictwie (40000), wyrażone } \\
\text { w AWU }\end{array}$ & aact_ali01 \\
\hline & kapitał & $\begin{array}{l}\text { wartość zużycia pośredniego (19000) i amortyzacji } \\
\text { (21000) w euro, w cenach stałych z } 2005 \text { roku }\end{array}$ & aact_eaa03 \\
\hline & ziemia & całkowita powierzchnia użytków rolnych w ha & aei_pr_gnb \\
\hline \multirow{4}{*}{ 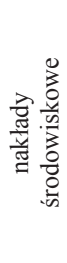 } & $\begin{array}{l}\text { emisja gazów } \\
\text { cieplarnianych }\end{array}$ & $\begin{array}{c}\text { emisja } \mathrm{CO}_{2} \mathrm{w} \text { tonach oraz } \mathrm{N}_{2} \mathrm{O}, \mathrm{CH}_{4}, \mathrm{HFC}, \mathrm{PFC}, \mathrm{SF}_{6} \text {, } \\
\mathrm{NF}_{3} \text { w tonach ekwiwalentu } \mathrm{CO}_{2}\end{array}$ & env_air_gge \\
\hline & $\begin{array}{l}\text { bilans składników } \\
\text { odżywczych }\end{array}$ & saldo składników odżywczych (azotu) w tonach & aei_pr_gnb \\
\hline & emisja amoniaku & roczna emisja $\mathrm{NH}_{3}$ pochodzenia rolniczego, w tonach & env_air_emis \\
\hline & $\begin{array}{l}\text { intensywność obsady } \\
\text { zwierząt }\end{array}$ & ilość LSU przypadających na 1 ha UR & ef_kvftaa \\
\hline$\frac{\frac{3}{2}}{\frac{\mathbb{d}}{d}}$ & produkcja & $\begin{array}{c}\text { wartość produkcji dóbr rolniczych - roślinnej i } \\
\text { zwierzęcej (14000) w euro, w cenach bazowych (z } \\
\text { uwzględnieniem subwencji do produkcji), w cenach } \\
\text { stałych z } 2005 \text { roku }\end{array}$ & aact_eaa03 \\
\hline
\end{tabular}

Źródło: opracowanie własne na podstawie metodyki Eurostat. Pobrano: 07.07.2017.

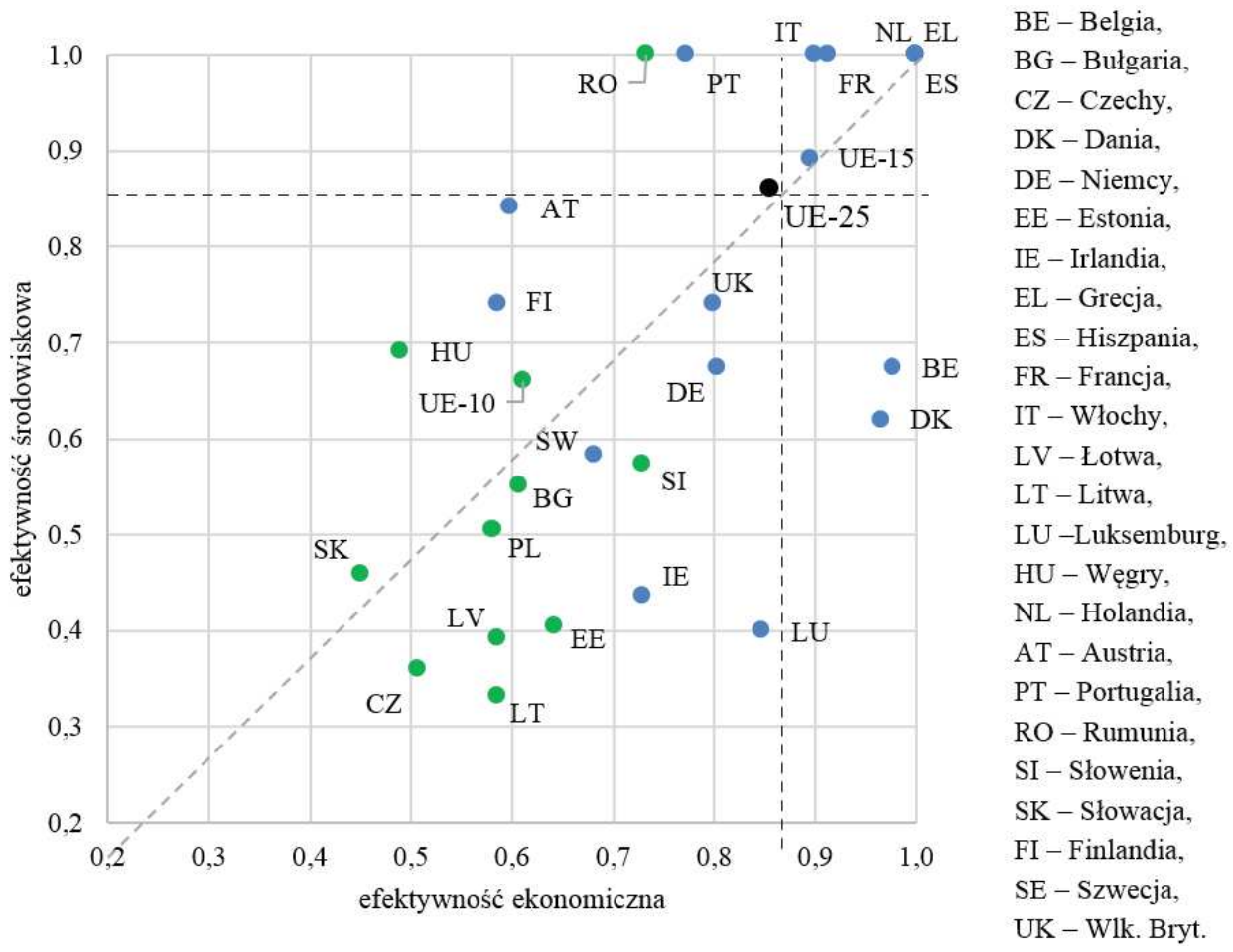

Rys. 2. Poziom efektywności ekonomicznej i środowiskowej w roku bazowym (2005) - metoda DEA

Fig. 2. Level of economic and environmental efficiency in the base year (2005) - DEA method

Źródło: opracowanie własne na podstawie danych Eurostat. Pobrano: 07.07.2017. 
Wartość indeksu TFP Malmquista dla analizowanego okresu stanowi średnią harmoniczną wartości z poszczególnych lat. Ze zbiorowości 28 krajów UE, badanie nie obejmuje Cypru i Malty, które stanowiły obserwacje odstające oraz Chorwacji, dla której niedostępne były dane dotyczące całego analizowanego okresu. Obliczeń efektywności dokonano w programie DEAP 2.1.

\section{Wyniki badań}

Na rys. 2. przedstawiono wyniki oszacowań efektywności nakładów ekonomicznych i środowiskowych rolnictwa dla bazowego roku 2005. Na podstawie oszacowań tych określone zostały optymalne ścieżki zrównoważonej intensyfikacji. W większości krajów (14 z 25) wyższa pozostawała efektywność nakładów ekonomicznych, co oznacza, że w ich przypadku pożądany jest większy przyrost produktywności środowiskowej.

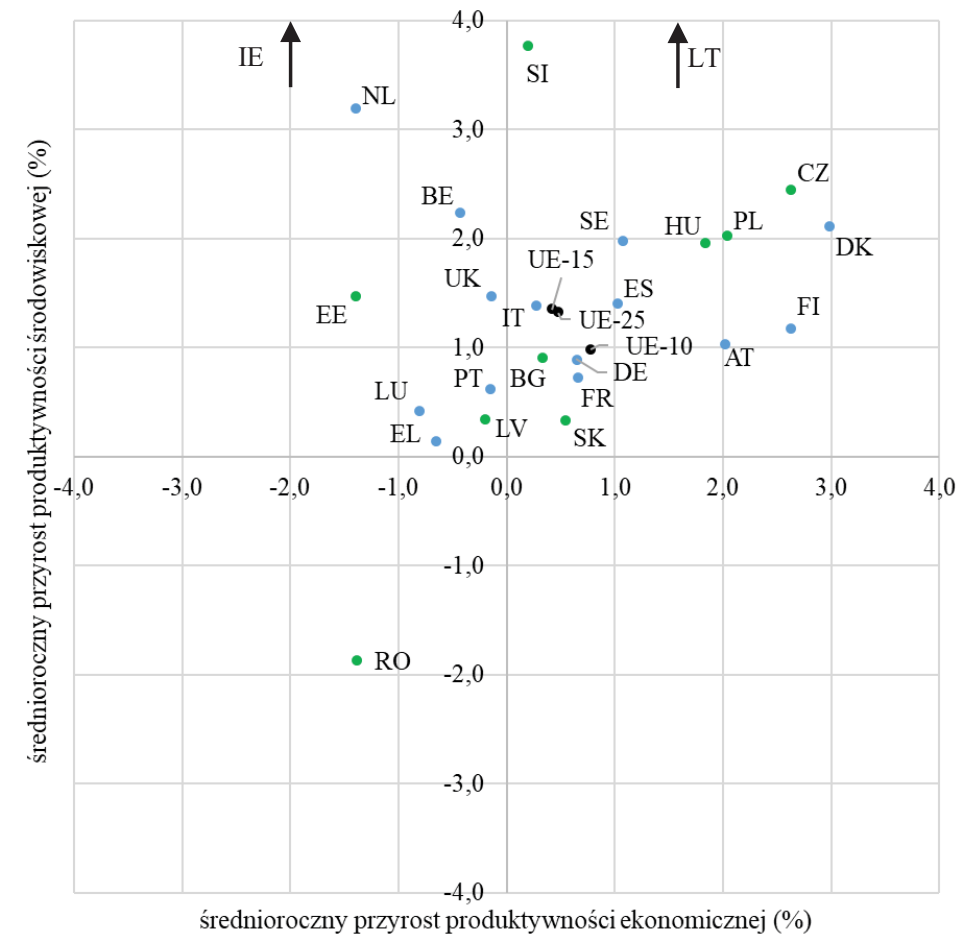
$\mathrm{BE}$ - Belgia,
BG - Bułgaria
CZ - Czechy,
DK - Dania,
DE - Niemcy,
EE - Estonia,
IE - Irlandia,
EL - Grecja,
ES - Hiszpania,
FR - Francja,
IT - Włochy,
LV - Łotwa,
LT - Litwa,
LU -Luksemburg,
HU - Węgry,
NL - Holandia,
AT - Austria,
PT - Portugalia,
RO - Rumunia,
SI - Słowenia,
SK - Słowacja,
FI - Finlandia,
SE - Szwecja,
UK - Wlk. Bryt.

Rys. 3. Średnioroczne zmiany produktywności ekonomicznej i środowiskowej rolnictwa w krajach Unii Europejskiej - indeks TFP Malmquista

Fig. 3. Average annual changes in economic and environmental productivity of agriculture in the European Union countries - Malmquist TFP index

Źródło: opracowanie własne na podstawie danych Eurostat. Pobrano: 07.07.2017. 
Zidentyfikowano generalnie niższą w obydwu obszarach efektywność w krajach UE10 (będących wówczas krótko po akcesji lub na chwilę przed nią). Co nietypowe, przeciętna, ważona wartością produkcji efektywność w tej grupie była wyższa w wymiarze środowiskowym. Związane jest to $\mathrm{z}$ wyjątkowo dobrymi wynikami Rumunii, zawyżającymi wielkość średnią. Wartości przeciętne dla całej zbiorowości wskazywały na potrzebę równomiernej poprawy w obydwu obszarach. Zidentyfikować można jednak kraje, gdzie wymagana była znacznie wyższa poprawa w wymiarze ekonomicznym (Rumunia, Portugalia, Włochy, Francja) lub w środowiskowym (Dania i Belgia). Zmiany jakie nastąpiły w obszarze produktywności całkowitej ilustruje rys. 3 .

Tabela 2. Wskaźnik zrównoważonej intensyfikacji i jego elementy składowe

Table 2. The sustainable intensification indicator and its components

\begin{tabular}{|c|c|c|c|}
\hline Wyszczególnienie & odległość & mnożnik kierunkowy & wskaźnik SI \\
\hline Belgia & 2,20 & $-0,13$ & $-0,28$ \\
\hline Bułgaria & 0,96 & 1,77 & 1,71 \\
\hline Czechy & 3,59 & 1,89 & 6,79 \\
\hline Dania & 3,66 & 1,45 & 5,32 \\
\hline Niemcy & 1,10 & 1,95 & 2,16 \\
\hline Estonia & 2,02 & $-0,48$ & $-0,98$ \\
\hline Irlandia & 4,72 & $-0,27$ & $-1,29$ \\
\hline Grecja & 0,67 & $-0,86$ & $-0,58$ \\
\hline Hiszpania & 1,74 & 1,90 & 3,31 \\
\hline Francja & 0,97 & 1,46 & 1,42 \\
\hline Włochy & 1,42 & 1,12 & 1,59 \\
\hline Lotwa & 0,39 & $-0,32$ & $-0,13$ \\
\hline Litwa & 4,13 & 1,73 & 7,16 \\
\hline Luksemburg & 0,92 & $-0,70$ & $-0,64$ \\
\hline Węgry & 2,68 & 1,83 & 4,90 \\
\hline Holandia & 3,50 & $-0,26$ & $-0,92$ \\
\hline Austria & 2,27 & 1,93 & 4,39 \\
\hline Polska & 2,87 & 1,95 & 5,59 \\
\hline Portugalia & 0,65 & $-0,16$ & $-0,11$ \\
\hline Rumunia & 2,32 & $-1,81$ & $-4,21$ \\
\hline Słowenia & 3,76 & 1,68 & 6,31 \\
\hline Słowacja & 0,64 & 1,85 & 1,19 \\
\hline Finlandia & 2,87 & 1,92 & 5,51 \\
\hline Szwecja & 2,26 & 1,9 & 4,29 \\
\hline Wlk. Bryt. & 1,48 & $-0,06$ & $-0,09$ \\
\hline UE-10 & 1,25 & 1,89 & 2,37 \\
\hline UE-15 & 1,41 & 1,69 & 2,38 \\
\hline UE-25 & 1,40 & 1,70 & 2,38 \\
\hline
\end{tabular}

Źródło: opracowanie własne na podstawie metodyki Eurostat. Pobrano: 07.07.2017. 
Przeciętne dla UE-25 wartości indeksu Malmquista były dodatnie zarówno w aspekcie ekonomicznym, jak i środowiskowym. Również wartości przeciętne dla zbiorowości UE10 i UE-15 wskazują, że rozwijały się one zgodnie z założeniami SI. Tempo poprawy produktywności ekonomicznej było wyższe dla krajów UE-10, zaś środowiskowej dla UE15. Wyższe było też ogólne tempo zmian produktywności środowiskowej. 15 z 25 krajów znalazło się w II części wykresu, reprezentującej zrównoważoną intensyfikację. Ponadto tylko jeden kraj nie poprawił wyników produktywności środowiskowej (Rumunia). Wśród krajów, które szczególnie dynamicznie poprawiały produktywność ekonomiczną i środowiskową znalazły się Czechy, Polska i Dania. W zakresie produktywności środowiskowej najlepiej wypadły Irlandia, Litwa i Słowenia. Powyższe wyniki syntetyzuje tabela 2., gdzie przedstawiono oszacowany wskaźnik zrównoważonej intensyfikacji oraz jego elementy składowe.

Jeżeli chodzi o zbieżność kierunku zmian z wyznaczonym optimum, to najlepiej wypadły Polska, Niemcy i Austria (współczynnik kierunkowy bliski 2). Niektóre kraje odnotowały mimo wysokiej dynamiki (wysoka wartość odległości euklidesowej) nieco gorsze wyniki, ze względu na niewłaściwe ukierunkowanie zmian. Wśród państw, gdzie nadmiernie względem produktywności ekonomicznej poprawiała się produktywność środowiskowa wskazać można Francję, Włochy i Bułgarię zaś wśród krajów o odwrotnej zależności Danię. W końcu wskazać można szereg państw, gdzie sektor rolny rozwijał się w sposób niezgodny z paradygmatem zrównoważonej intensyfikacji. Cechują je ujemne wartości wskaźnika SI. Są to głównie kraje, które poprawiały efektywność ekonomiczną kosztem środowiskowej. Wyjątkiem jest Rumunia, która zanotowała pogorszenie wskaźników w obydwu wymiarach, przez co również notuje najniższą wartość wskaźnika SI. Porównując kraje UE-10 i UE-15 zauważyć można, że cechowały się one przeciętnie podobną wartością wskaźnika SI. W przypadku UE-15 większa była dynamika, lecz gorsze ukierunkowanie zachodzących zmian. Wśród krajów UE-10 sytuacja była odwrotna.

\section{Wnioski}

Zaproponowana metoda pomiaru zrównoważonej intensyfikacji w rolnictwie krajów UE, $\mathrm{z}$ wykorzystaniem metody DEA, indeksu TFP Malmquista oraz odległości euklidesowych i kątowych pozwoliła na uchwycenie dynamiki procesu, który utożsamiać można do pewnego stopnia z rozwojem trwale równoważonym. Na podstawie uzyskanych wyników sformułować można następujące wnioski:

- $\quad$ zidentyfikowano postępujący w skali UE proces zrównoważonej intensyfikacji, co zbieżne jest z założeniami wspólnej polityki rolnej i celami strategii EUROPA 2020. Choć w niektórych krajach zaobserwować można było w latach 2005-2013 ujemne wskaźniki produktywności ekonomicznej, to przeciętnie w skali UE syntetyczny wskaźnik SI był dodatni;

- zjawiskiem marginalnym była ujemna wielkość indeksu produktywności środowiskowej. Większe były również przeciętne wartości przyrostów $\mathrm{w}$ tym wymiarze, co potwierdza prymat celu ekologizacji rolnictwa UE w ostatnich latach. Może to również wynikać $\mathrm{z}$ faktu, że możliwości poprawy ekonomicznej efektywności produkcji rolnej w warunkach UE, szczególnie zaś krajów UE-15 wyczerpują się, a dalszy postęp w zakresie zrównoważonej intensyfikacji możliwy 
będzie raczej dzięki zwiększaniu produktywności zasobów środowiskowych, niż ekonomicznych;

- również w przypadku krajów UE-15 zauważalne jest silniejsze nakierunkowanie na poprawę produktywności środowiskowej, niż wynikałoby to $\mathrm{z}$ wyznaczonych optymalnych ścieżek wzrostu. Wynikać może to z silniejszej w tych krajach presji na ekologizację metod produkcji, pochodzącej od konsumentów.

- w kontekście krajów UE-10, jako problem wskazać można niższą dynamikę procesu zrównoważonej intensyfikacji, podważającą możliwość konwergencji z krajami UE-15;

- chcąc rozwijać zaprezentowany $\mathrm{w}$ artykule kierunek badań zrównoważonej intensyfikacji rolnictwa rozważyć należy rozszerzenie badań o wymiar społecznej efektywności działalności rolniczej, zastosowanie stochastycznych metod szacowania efektywności, przeniesienie analizy na poziom regionalny oraz identyfikację determinant zróżnicowania $\mathrm{w}$ tempie procesu zrównoważonej intensyfikacji.

\section{Literatura}

Baráth, L., Fertö, I. (2017). Productivity and Convergence in European Agriculture. Journal of Agricultural Economics, 68(1), 228-248.

Buckwell, A., Uhre, A. N., Williams, A., Polakova, J., Blum, W., Schiefer, J., Lair, G. J, Heissenhuber, A., Schieß1, P., Krämer, C., Haber W. (2014). The sustainable intensification of European Agriculture. Brussels: RISE Foundation http://www.risefoundation.eu/images/files/2014/2014_20SI_RISE_FULL_EN.pdf.

Czyżewski, A. (2015). Odkrywanie ekonomii rolnej (Discovering agricultural economics). Wykład z okazji nadania godności Doktora Honoris Causa Szkoły Głównej Gospodarstw Wiejskiego w Warszawie, 26 listopada 2015 r., Warszawa.

Czyżewski, A., Smędzik, K. (2010). Efektywność techniczna i środowiskowa gospodarstw rolnych w Polsce według ich typów i klas wielkości w latach 2006-2008 (Technical and environmental efficiency of farms in Poland in 2006-2008, according to their types and sizes). Roczniki Nauk Rolniczych, Seria G, 97(3), 61-71.

Czyżewski, A., Staniszewski J. (2018). Dylematy operacjonalizacji paradygmatu zrównoważonego rozwoju rolnictwa z wykorzystaniem pojęcia ekoefektywności (Dilemmas of the operationalisation of the sustainable agriculture development paradigm with eco-efficiency measures). Problemy Rolnictwa Światowego, 18(2), $44-56$.

Färe, R., Grosskopf, S., Norris, M., Zhang, Z. (1994). Productivity growth, technical progress and efficiency change in Industrialised Countries. The American Economic Review, 84(1), 66-83.

Floriańczyk, Z., Rembisz, W. (2012). Dochodowość a produktywność rolnictwa polskiego na tle rolnictwa unijnego w latach 2002-2010 (Profitability and Productivity of Polish Agriculture Versus Those of EU Agriculture in 2002-2010). Problemy Rolnictwa Światowego, 12(1), 53-62.

Gadanakis, Y., Bennett, R., Park, J., \& Areal, F. J. (2015). Evaluating the Sustainable Intensification of arable farms. Journal of Environmental Management, 150, 288-298.

Klepacki, B., Gołasa, P., Wysokiński, M. (2016). Efektywność emisji gazów cieplarnianych w rolnictwie Unii Europejskiej (Efficiency of Greenhouse Gas Emissions in European Union Agriculture). Wieś i Rolnictwo, $3(172), 129-144$

Kuosmanen, N. (2014). Estimating stocks and flows of nitrogen: Application of dynamic nutrient balance to European agriculture. Ecological Economics, 108, 68-78.

Lampkin, N. H., Pearce, B. D., Leake, A. R., Creissen, H., Gerrard, C. L., Girling, R., Lloyd, S., Padel, S., Smith, J., Smith, L.G., Vieweger, A., Wolfe, M.S. (2015). The Role of Agroecology in Sustainable Intensification. Pobrano z: http://www.snh.gov.uk/docs/A1652615.pdf

Staniszewski, J. (2017a). Koncepcja zrównoważonej intensyfikacji rolnictwa w państwach Unii Europejskiej (The sustainable agriculture intensification concept in the European Union countries). Przeglad Zachodni, $2,233-246$. 
Staniszewski, J. (2017b). Zrównoważona intensyfikacja rolnictwa - kierunki operacjonalizacji (Sustainabile Intensification of Agriculture - the Operationalisation Directions), Roczniki Naukowe SERiA, 19(2), 220223

Turčeková, N., Svetlanská, T., Kollár, B., Záhorský, T. (2015). Agri-Environmental Performance of EU Member states. Agris on-line Papers in Economics and Informatics, 7(4), 199-208.

Do cytowania / For citation:

Czyżewski A. Staniszewski J. (2018). Zrównoważona intensyfikacja rolnictwa jako kombinacja efektywności nakładów ekonomicznych i środowiskowych. Problemy Rolnictwa Światowego, 18(3), 80-90; DOI: 10.22630/PRS.2018.18.3.68

Czyżewski A. Staniszewski J. (2018). Sustainable Intensification of Agriculture as the Composition of Economic Productivity and Environmental Pressure Measures (in Polish). Problems of World Agriculture, 18(3), 80-90; DOI: 10.22630/PRS.2018.18.3.68 